\title{
Evaluation of alpha-methylacyl-CoA racemase, metallothionein and prostate specific antigen as prostate cancer prognostic markers
}

\author{
J. GUMULEC ${ }^{1,2,3}$, M. MASARIK ${ }^{1,2,3}$, S. KRIZKOVA ${ }^{2,3}$, M. HLAVNA ${ }^{1}$, P. BABULA ${ }^{2,3}$, R. HRABEC ${ }^{4}$, A. ROVNY ${ }^{4}$, M. MASARIKOVA ${ }^{2,3}$, J. SOCHOR ${ }^{2,3}$, \\ V. ADAM ${ }^{2,3}$, T. ECKSCHLAGER ${ }^{5}$, R. KIZEK ${ }^{2,3, *}$
}

${ }^{1}$ Department of Pathological Physiology, Faculty of Medicine, Masaryk University, Kamenice 5, CZ-625 00 Brno, Czech Republic; ${ }^{2}$ Department of Chemistry and Biochemistry, Mendel University in Brno,Zemedelska 1, CZ-613 00 Brno, Czech Republic; ${ }^{3}$ Central European Institute of Technology, Brno University of Technology, Technicka 3058/10, CZ-616 00 Brno, Czech Republic; ${ }^{4}$ Department of Urology, St. Anne's University Hospital Brno,Pekarska 53/55, CZ-656 91 Brno, Czech Republic; ${ }^{5}$ Department of Paediatric Haematology and Oncology, 2nd Faculty of Medicine Charles University, and University Hospital Motol, V Uvalu 84, CZ-150 06 Praha 5, Czech Republic

${ }^{*}$ Correspondence: kizek@sci.muni.cz

Received September 20, 2011 / Accepted October 17, 2011

\begin{abstract}
Current diagnostic techniques are inefficient in distinguishing latent and low-risk forms of prostate cancer from high-risk forms. The present study is focused on determination of putative tumor markers of aggressive high-grade forms of prostate cancer. Potential markers were determined in blood sera of 133 patients ( 82 cases and 51 controls) and in cell lines (Gleason score 9-derived 22Rv1 and normal tissue derived PNT1A) on mRNA and protein levels. Alpha-methylacyl-CoA racemase (AMACR), metallothionein classes 1A and 2A (MT1A and MT2A) were determined and compared to prostate specific antigen (PSA) levels. On mRNA level, significantly increased expression of MT2A (2.4-fold), PSA (2.6-fold) and AMACR (8.4-fold) and insignificantly (1.9-fold) elevated MT1A in 22Rv1 compared to non-tumor PNT1A were determined. On protein level, significant enhancement of free PSA and total PSA in tumor cell line was evident. AMACR protein was 1.5-fold elevated in tumor line (below the level of significance). Contrary to mRNA, significantly $(p=0.01)$ reduced level of MT protein in tumor lines was determined. In the case of serum level, significantly enhanced MT level (4.5-fold) in patients' sera was found. No significant changes were observed in the case of AMACR. These findings indicate possible alternative role of MT to PSA prostate cancer marker. In addition, level of AMACR is distinctly higher in the Gleason score 9 in serum of patients and MT shows a descending trend in relation to Gleason score.
\end{abstract}

Keywords: cancer, tumor marker, immunodetection, electrochemistry, polymerase chain reaction, $m R N A$

Prostate carcinoma is one of the most studied oncological diseases due to its high incidence in male population. It represents one of the most frequent cancers in developed countries and common cause of cancer-related death $[1,2]$. Recently significantly increased number of newly diagnosed patients suffering from this malignant disease is directly related to introduction of prostatic specific antigen (PSA) evaluation to the clinical practice [3-7]. This marker enabled detection of early stages of disease, undetectable when commonly used rectal investigation is employed. PSA screening contributed towards $20 \%$ reduction of mortality. It is well evident from the study focused on the European medical institutes published in the prestigious New England Journal of Medicine [8]. Ascertained reduction of mortality is caused by the fact that PSA screening is able to detect early stages $\mathrm{T} 1$ and $\mathrm{T} 2$ of prostate carcinoma, otherwise non-detectable by the conventional methods, such as digital rectal investigation. Tumors of stage T3 and T4, which are usually associated with tissue invasion or metastasizing, are often incurable and the therapeutic approach is based on a palliative treatment only. Despite the evident benefit of PSA evaluation, digital rectal investigation has its importance in the diagnostics and it should not be neglected by a general practitioner $[9,10]$. Besides PSA, there have been identified and tested other markers [11-16], including those detected in urine [17].

On the other hand, it is necessary to accentuate that a large amount of tumors is asymptomatic (up to $80 \%$ ). They are usually evidenced only at dissection of departed in connection with other cause of disease or at surgery [17]. Based of above mentioned facts, it is proper to sub-classify prostate tumors into two groups: 1. significant tumor swith direct risk 


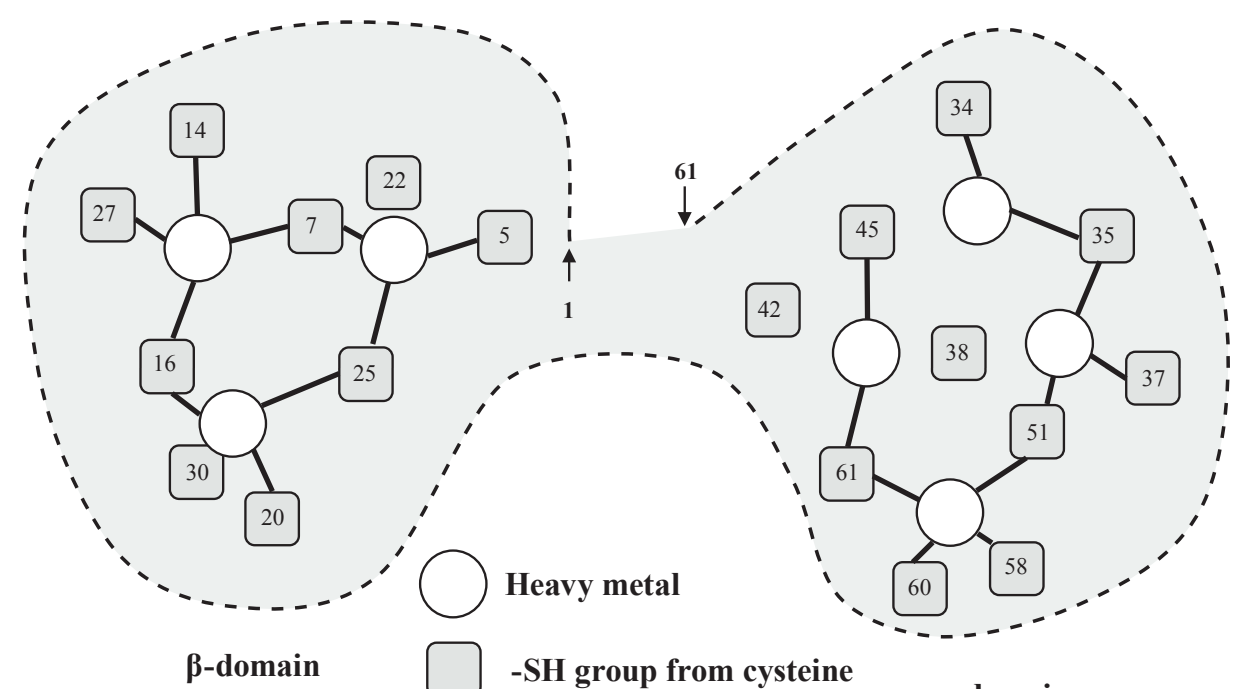

Figure 1. Structure of human metallothionein containing seven divalent ions.

to a life; 2 . non-significant tumors, where risk to a life is highly improbable. Currently used diagnostic methods including PSA determination, digital rectal examination, transrectal ultrasonography or biopsy, are not able to differentiate between aggressive and latent forms of tumor. All bioptically (histologically) verified prostate carcinomas are treated as significant, dangerous tumors with direct risk. This therapeutic approach leads to the significant reduction of quality of life because of important side effects of the treatment. Erectile dysfunction is detected in more than $70 \%$ and urinary incontinence in approximately $10 \%$ of patients after radical prostatectomy. However, there is significant rate of patients who are treated in vain[18]. Due to these facts, it is quite necessary to find such prostate carcinoma markers that are useful for distinction of aggressive and latent tumor forms already at early stages of the disease[19-30]. Metallothionein (MT) and alpha-methyl CoA-racemase (AMACR) belong to the possible markers of prostate carcinoma at early stages, but their clinical potential must be still investigated.

Metallothioneins (MT) represent proteins of low molecular weight $(6-10 \mathrm{kDa})$ with high rate of cysteine (Fig. 1). Presence of - $\mathrm{SH}$ group-containing amino acids is directly connected with the ability of these proteins to bind various metal ions [31-33]. Therefore, metallothioneins play a crucial role in transport of metal ions, their detoxification and protection of cells against oxidative stress connected with effects of the metal ions [34]. These proteins are involved also in regulation of apoptosis; their increased levels have antiapoptotic effect. In addition, metallothioneins regulate level, activity and cellular localisation of transcriptional factor NF- $\kappa \mathrm{B}$, which activates antiapoptotic genes Bcl-2, c-myc and TRAF-1 that belong to the group of prooncogenes. This antiapoptotic cascade can be efficient as the protective mechanism of prostate carcinoma cells against apoptotic signals at their proliferation $[35,36]$.
Alpha-methyl CoA-racemase (AMACR) is peroxisomal and mitochondrial enzyme involved in beta oxidation of branched fatty acids, catabolism of bile acids metabolites and ibuprofen metabolism [37]. Ibuprofen belongs to a class of drugs called non-steroidal anti-inflammatory drugs, such as aspirin. They are used for the management of mild to moderate pain, fever, and inflammation. Increased levels of AMACR have been described in adenocarcinomas and high grade prostatic intraepithelial neoplasia [38]. On the other hand, low levels of this marker have been described in benign hyperplasia and in atypical adenomatous hyperplasia [3941]. Thus, AMACR is well established tissue prostate cancer biomarker [41]. Moreover, it has been demonstrated that high level of AMACR affects progression of prostate cancer due to 1. more energy-efficient utilization of fatty acids [39], 2. AMACR-substrate-mediated oxidative stress, and 3. affection of nuclear hormone receptors.

Cellular processes in prostate carcinoma cells were investigated especially using cell lines LNCaP (androgen-sensitive), PC-3 (androgen-resistant), and DU 145 (androgen-resistant). These lines don't represent ideal model because they differ from in vivo state and they are derived not from primary tumor but from metastatic dissemination in bones (PC-3), brain (DU 145), and lymphatic nodes (LNCaP). Cell line 22Rv1 represents poorly differentiated primary prostate adenocarcinoma of Gleason grading score 9. Cell line expresses androgen receptor (AR) and synthesizes high amounts of PSA [42]. Cell line 22Rv1 is more suitable model of prostate adenocarcinoma because of reduced genetic variability and lower rate of aneuploidy - karyotype $50 \mathrm{XY}$ (trisomy of 7, 8, 12), DNA index 1.30 (PC-3: 1.84 and LNCaP: 2.09) in comparison with other cell lines [42].

Aim of the present study was to compare the level of putative prostate cancer markers in sera of patients with prostate cancer and healthy volunteers and to compare the expression 

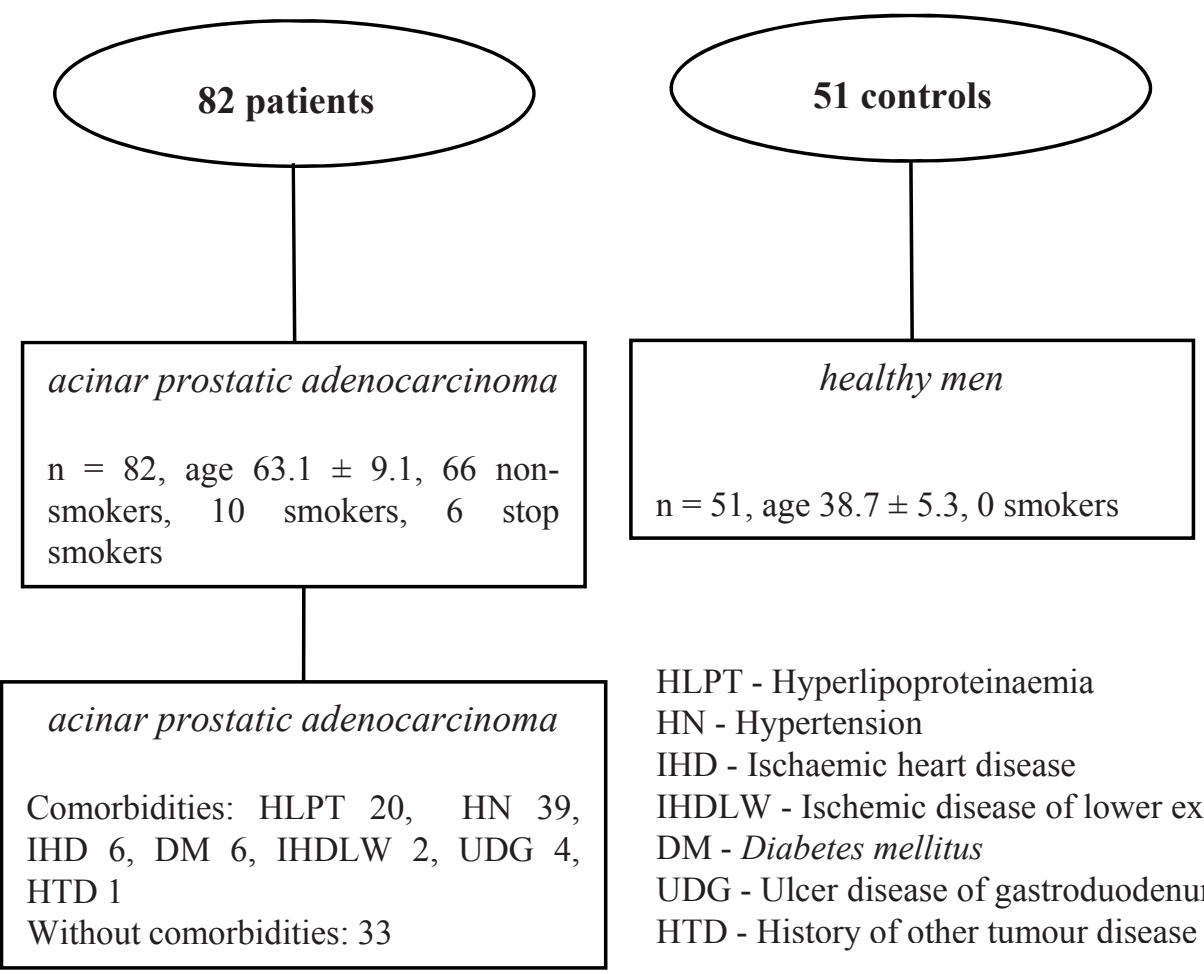

HLPT - Hyperlipoproteinaemia

$\mathrm{HN}$ - Hypertension

IHD - Ischaemic heart disease

IHDLW - Ischemic disease of lower extremities

DM - Diabetes mellitus

UDG - Ulcer disease of gastroduodenum

HTD - History of other tumour disease

Figure 2. Characteristics of patients and healthy men included in the study.

of these markers and other proteins connected with tumor behaviour (apoptosis regulation, invasivity and zinc metabolism) on mRNA and protein level in 22Rv1 prostate cancer cell line and control prostate cell line.

\section{Material and Methods}

Cell lines, blood sera. Control cell line derived by immortalisation of normal prostatic epithelial cells of 35-year old man obtained post mortem (PNT1A) and 22Rvl cell line derived from xenograft passaged on castrated mice were used in this study. These cell lines were purchased from the HPA Culture Collections (Salisbury, UK). 22Rv1 and PNT1A cells were cultured in RPMI-1640 medium with 10\% FBS. Medium was supplemented with penicillin and streptomycin $(1 \mathrm{U} / \mathrm{mL})$, and the cells were maintained at $37^{\circ} \mathrm{C}$ in a humidified incubator with $5 \% \mathrm{CO}_{2}$. Sub-cultivations of the cells were carried out after 21 days. Once the cells grew up to $\sim 75 \%$ confluence of the culture, the cultivation medium was replaced by fresh medium for $24 \mathrm{~h}$ to synchronize cell growth. Proteins from these cell lines and from tested blood sera of patients were isolated by the use of RIPA buffer by the mechanical homogenisation or heat denaturation $\left(99^{\circ} \mathrm{C}\right)$ of obtained material. Heat lysates were subsequently subjected to electrochemical determination of MT, PSA and AMACR was determined in RIPA lysates.

Patients with diagnosed prostate carcinoma. Blood sera of patients with histologically verified prostate adenocarcinoma
(82 samples) were compared to 51 controls (Fig. 2). Average age of patients was 63 years (40-78). Tumors were classified from high to low differentiated tumors with Gleason score, describing rate of tumor differentiation, in the range between 5 and 10. Pathological staging of samples varied from $1 \mathrm{c}$ to 4 , all patients were without dissemination into adjacent lymphatic nodes or organs. There were $80 \%$ of non-smokers, $12 \%$ of smokers and $8 \%$ of stop-smokers in the set. Forty percent of patients were without co-morbidities, $37 \%$ of patients suffered from one co-morbidity, $7 \%$ of patients had 2 and the rest of patients had 3 and more co-morbidities. Hyperlipoproteinaemia was diagnosed in $24 \%$ of patients, hypertension in $47 \%$, ischemic heart disease in $7 \%$, diabetes mellitus of the second type in $7 \%$, ischemic disease of lower extremities in $2 \%$, ulcer disease of gastroduodenum in 5\%, and history of other tumor disease in $1 \%$ of patients. In the control group, there were 51 tested probands. Age of control group varied from 18 to 55 (38 at average). Tested blood sera were obtained from Urology clinic, St. Anne's University Hospital in Brno, Czech Republic. Enlistment of patients into realised clinical study was approved by the Ethic commission of the Faculty of medicine, Masaryk University, Brno, Czech Republic.

Polymerase chain reaction. High pure total mRNA isolation kit (Roche, Switzerland) was used for mRNA isolation from cell lines. Isolated mRNA was transcribed into cDNA by the use of Transcriptor first strand cDNA synthesis kit (Roche, Switzerland) in accordance with manufacturer's propositions. 
Real-time PCR was carried out by the system TaqMan using apparatus 7500 real-time PCR system (Applied Biosystems, USA). Results were evaluated in triplicates by the comparative Ct method $\left(2^{-\Delta \Delta C t}\right)$ and standardized against $\beta$-actin. The primer and probe sets for $\beta$-actin (Assay ID: Hs00185826_m1), MT1A (Assay ID: Hs00185826_m1), MT2A (Hs00794796_m1), AMACR (Hs01091294_m1), and PSA (Hs02576345_m1) were selected from TaqMan gene expression assay. Real-time PCR was performed under the following amplification conditions: total volume of $20 \mu \mathrm{L}$, initial denaturation $95^{\circ} \mathrm{C} / 10 \mathrm{~min}$, than 45 cycles $95^{\circ} \mathrm{C} / 15 \mathrm{sec}, 60^{\circ} \mathrm{C} / 1 \mathrm{~min}$. Samples were examined in quadruplicates.

Electrochemical detection of metallothionein. Electrochemical detection was used for quantification of metallothionein[43]. Detection was carried out using AUTOLAB Analyser (EcoChemie, Netherlands) with classical three-electrode arrangement using of differential pulse voltammetry Brdicka reaction. Analysed sample was accumulated on the surface of a working electrode which is represented by hanging mercury drop electrode. After accumulation, detection proceeded in a supporting electrolyte containing cobaltic (cobalt(III)) salt in ammonia buffer of $\mathrm{pH}=9.6[33,44]$.

Gel electrophoresis, western blotting. Samples were separated on $10 \%$ SDS-PAGE gels (BioRad, USA) and stained by silver nitrate (kit BioRad, USA, under manufacturer's propositions) and simultaneously blotted on a nitrocellulose membrane and immunodetected by specific antibodies. Dotblots were used for rapid orientation. Serum samples were 8 -fold diluted. Membranes were incubated for $1 \mathrm{~h}$ in $5 \%$ milk and for $12 \mathrm{~h}$ in primary antibody (1:500), washed and incubated in secondary antibody (1:2000). Polyclonal rabbit antibody (Santa Cruz Biotechnology, USA) was used against metallothionein, isoforms 1 and 2, polyclonal rabbit antibody (Clonestar, CZ) was used against AMACR. Monoclonal mouse antibody (Santa Cruz Biotechnology, USA) was used for detection of PSA.

Descriptive statistics. Obtained results were evaluated using software Statistica 9 (StatSoft, USA). For better comparison of data sets, measured protein data were normalized to the range $0-1$. To disprove null hypothesis that cell line mRNA, protein and serum levels of specified genes are equal, $\mathrm{t}$-tests were used. Correlation matrices were used for finding of correlations between tested compounds. Cluster analysis (K-means) was employed for orientation in the set of patients. Significance level $\mathrm{p}=0.05$ was established for determination of significantly different value.

\section{Results}

Molecular-biological analysis of cell lines. Model of tumor tissue is represented by the cell line 22Rv1. The potential markers on the mRNA and protein levels were determined. mRNA level is expressed as a relative fold change of expression in comparison with non-malignantcell line PNT1A. Elevated expression of all studied markers in tumor cell line was ob- served. Statistically significant enhancement was detected in case of metallothionein - class 2A (MT2A, 2.4-fold expression in 22Rv1 compared to PNT1A, $p=0.006$, Fig. 3A), AMACR (8.4-fold, $p=0.0004$, Fig. 3B) and PSA (2.6-fold, $p=0.008$, Fig. $3 \mathrm{C}$ ) in the cancer line. Metallothionein class 1A expression level was only 1.9-fold higher in the tumor cell line (insignificant, $p=0.29$ ). In addition to mRNA level, the protein level of all three observed markers was also determined (Fig. 3D-F). Enhancement of free PSA and total PSA in tumor cell line was well evident at the protein level. AMACR was insignificantly elevated in the tumor line (1.5-fold, $\mathrm{p}=0.132)$. Interestingly, significantly $(\mathrm{p}=0.01)$ reduced level of metallothionein protein in tumor cells was observed (Fig. 3D).

Clinical study in patients suffering from malignant disease. Metallothionein, AMACR, free PSA and total PSA levels were detected in the blood serum of prostate cancer patients and volunteers to assess their applicability as markers of prostate cancer. Our group has previously shown that serum MT levels are elevated with high level of specificity and sensitivity in prostate cancer patients with possible application as an additional tool for prostate cancer diagnosis [23]. Compared to previous study, in this paper the group of tested samples has been enlarged. The levels of potential tumor markers were compared between each other to reveal potential relationship, which has never been done before for this combination of genes.

PSA was determined as a widely used marker to compare potential markers to it. Significantly higher PSA level $(\mathrm{p}=$ $0.001)$ and significantly $(\mathrm{p}<0.001)$ lower free/total PSA ratio in patients were observed. In addition, higher metallothionein content with high level of significance ( $p<0.0001$, Fig. 4 A) was well evident. This fact also supports the hypothesis that metallothionein is increasingly transported from prostate cancer cells to the extracellular space. Interestingly, metallothionein levels varied distinctly less than PSA levels in control group (displayed as a variation coefficient $14.1 \%$ and $75 \%$ for MT and PSA, respectively, Fig. 4B).This finding suggests that MT level is faintly affected by the tumor stage, grade, or clinical data. In terms of serum AMACR levels, no significant changes between patients and controls were detected in blood serum (Fig. 4C). No significant correlations between AMACR, MT and PSA were observed. Hierarchical tree clustering analysis of genes did not reveal any specific groups of patients (not shown).

In addition, correlations and t-tests were carried out with data obtained from clinical records. Subsequently, patients were divided into groups by presence of various common diseases, smoking habit, tumor size and its differentiation. No statistically significant differences between localised tumors $(\mathrm{T} 1,2)$ and tumors that extend through the prostate capsule $(\mathrm{T} 3,4)$, and monitored markers have been detected (data are not shown). As the tumor differentiation (good vs. medium vs. poorly differentiated) is concerned, significantly higher (1.8-fold, $\mathrm{p}=0.005)$ total PSA was determined in poorly differentiated tumors as compared to the others (data not shown). However, no similar correlation 


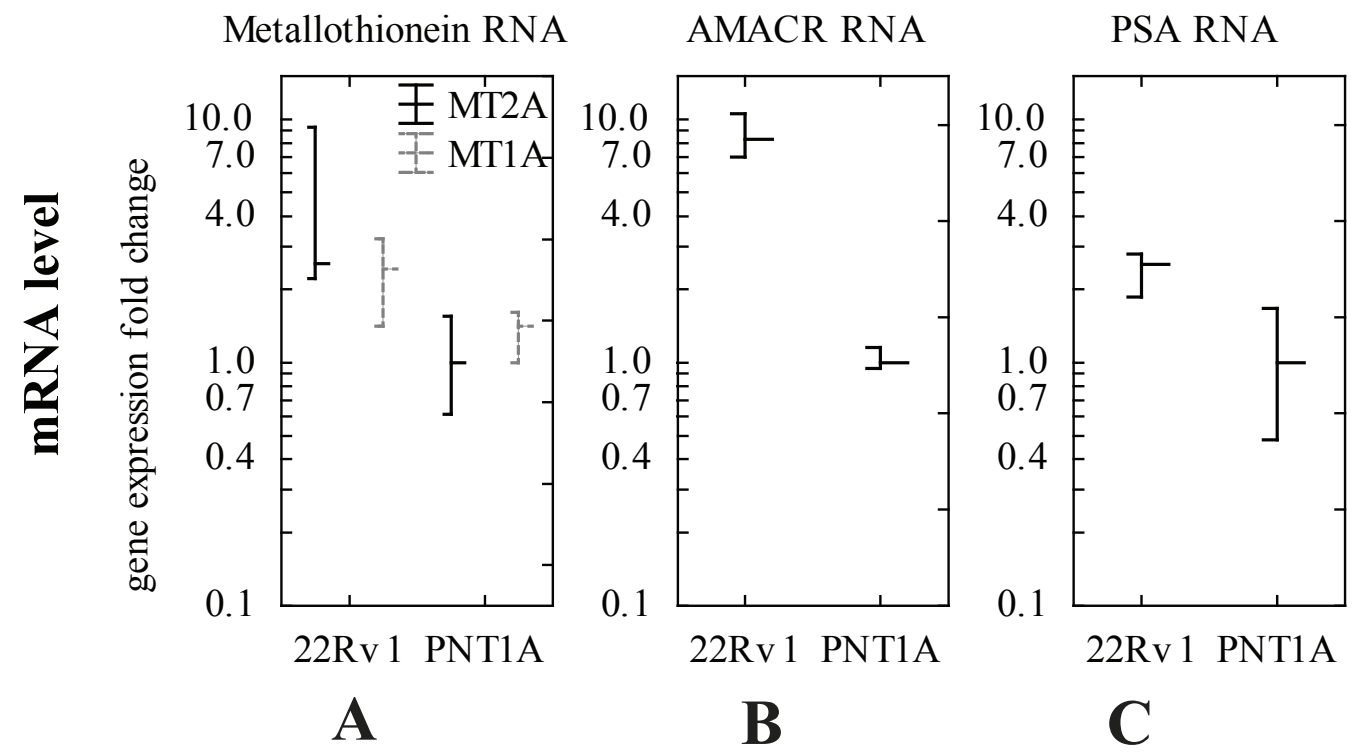

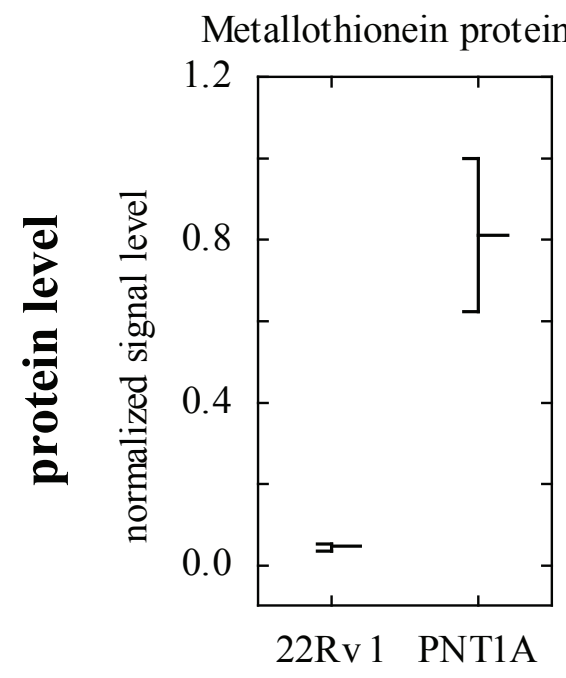

D
AMACR protein

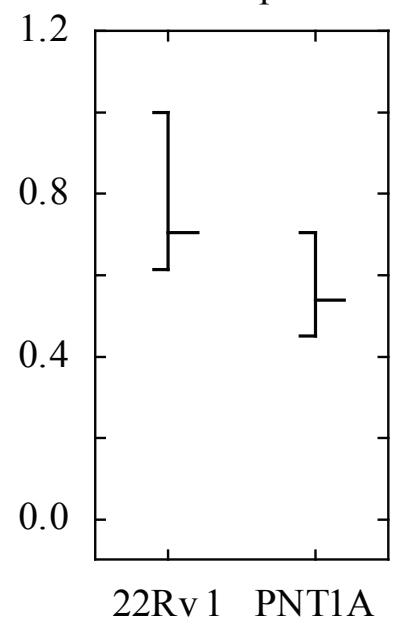

$\mathbf{E}$
PSA protein

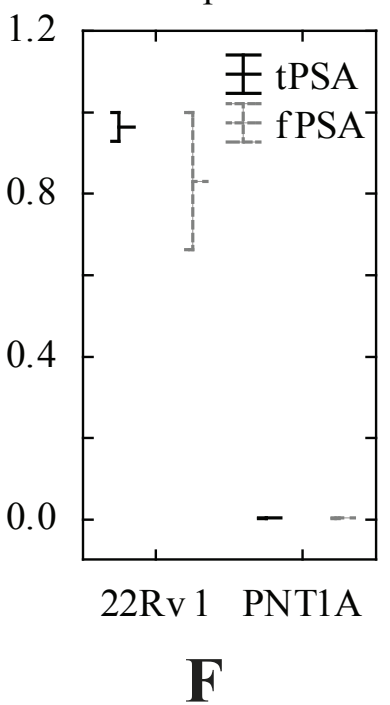

Figure 3. Levels of gene expression in cell lines. Level of mRNA genes expressed as relative fold change of expression (2- ${ }^{-\Delta \Delta C t}$ method) of tumor cell line (22Rv1) in comparison with non-tumor cell line PNT1A. (a) mRNA level of metallothionein classes 1A and 2A (MT1A, MT2A) in cell lines 22Rv1 (tumor) and PNT1A (non-tumor), (b) mRNA level of AMACR in cell lines, (c) mRNA level of PSA in cell lines, (d) metallothionein (protein content) in cell lines, (e) level of AMACR (protein content) in cell lines, (f) level of total (tPSA) and free PSA (fPSA) protein in cell lines.

was observed in AMACR and MT. Levels of monitored markers were not changed in connection with associated disease - hypertension, ischemic heart disease and hyperlipemia and duodenal ulcer. Significantly higher (2-fold) AMACR level in group of patients with ischemic disease of lower extremities was observed. However, due to the limited number of participants with this disease in this study $(\mathrm{N}=3)$ the robustness of this finding is limited and needs to be verified on larger file. No differences in monitored markers between smokers and non-smokers have been evident in all studied genes (data not shown).
Metallothionein showed an inverse, decreasing trend depending on Gleason grading (Fig. 4D). Increased level of metallothionein makes this protein possible candidate of tumor marker of prostate adenocarcinoma that is minimally influenced by the clinical status of the patient. Its level is not affected by smoking, age, and co-morbidities. Observed descending trend of serum MT in relation to Gleason grading score is interestingly an inverse one as compared to similar trend in PSA, and needs to be elucidated in further studies. No statistically important correlations between the age of 

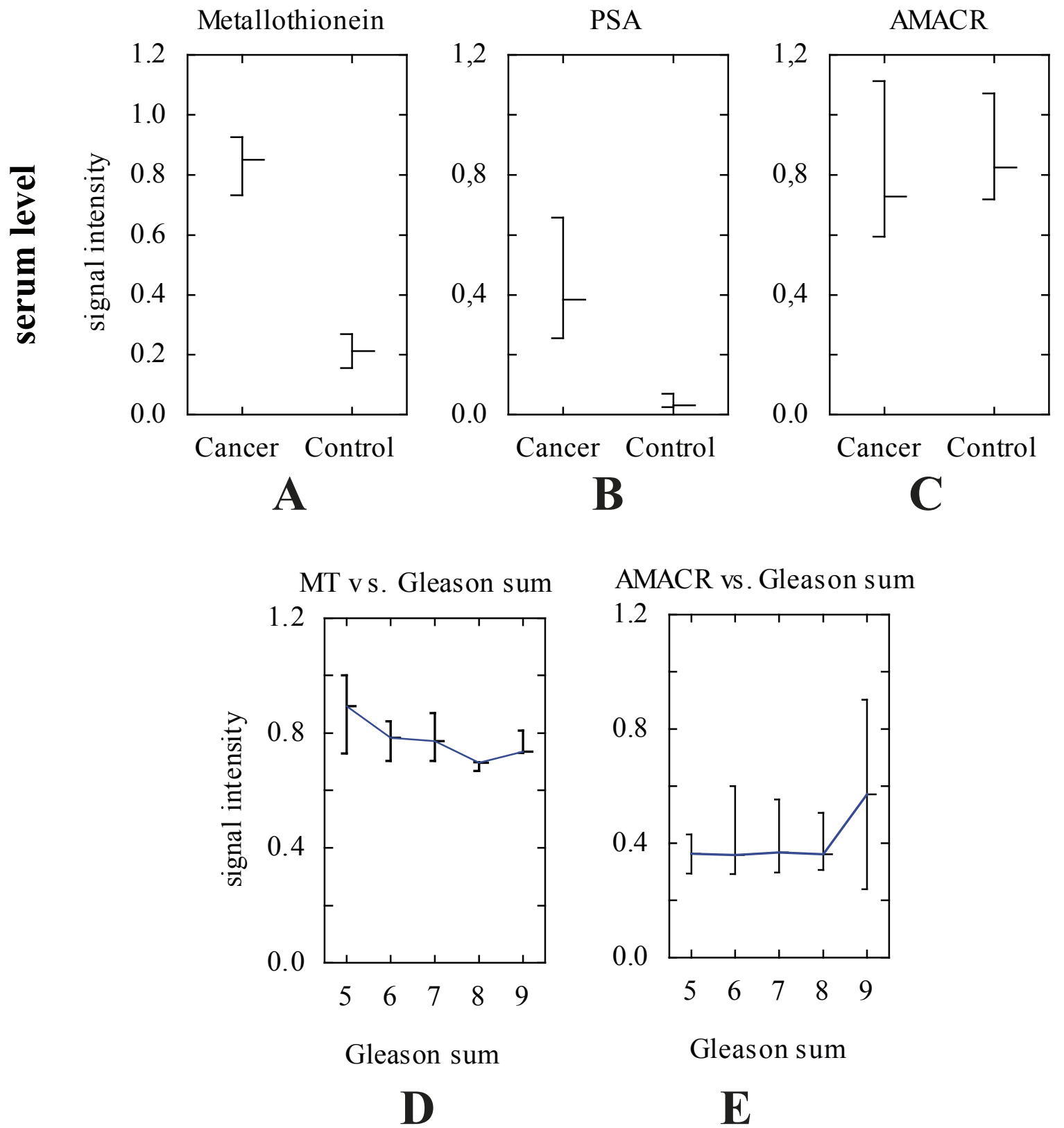

Figure 4. Level of tumor markers in blood serum of patients. (a) metallothionein, (b) PSA, (c) Alpha-methylacyl-CoA racemase (AMACR), (d) dependence of metallothionein level on the Gleason score, (e) dependence of AMACR on the Gleason score.

patients and all monitored proteins in serum were proved. In the dependence on Gleason grading score of malignant disease, AMACR did not show significant trend, however, was distinctly higher at T4 stage of TNM classification (Fig. 4E).

\section{Discussion}

The finding shown in Fig. 3 is in the contradiction with MT mRNA level. This fact suggests a conclusion that metallothionein is transported to the extracellular space by still unknown mechanisms (increased MT on mRNA and reduced MT on the protein level). Due to the transport of MT out of the cells, its level is significantly reduced in intracellular space. With respect to the MT relation to zinc ions, whose metabolism is abnormal in the prostate tumor tissue, MT participation on pathogenesis of malignant disorder can be expected [45-53]. To date, there is no evidence in the literature determining metallothionein level in 22Rv1 and PNT1A cell lines, however, there were done some experiments describing behaviour of RWPE-1 cell line, which revealed similarities of 
behaviour of this cell line with prostate tissue [54] as well as in the case of PC-3 cell line [55]. Moreover, it was found that MT was up-regulated under hypoxia in prostate cancer cells (LNCaP and PC-3) and overexpressed in prostate cancer tissue and residual cancer cells after androgen ablation therapy [56]. Besides other published studies, our finding is in agreement with results determining MT content in tissue samples. MT reduction in tumor tissue was reported by Suzuki et al. [57]. Similarly, Wong et al. presented lower MT content in the tumor tissue compared to benign prostatic hyperplasia $[58,59]$. The association between cadmium coming from smoking and MT on protein level and prostate carcinoma risk was also found [60], but the mRNA level of MT could be decreased in prostate carcinoma patients compared to benign hyperplasia ones both associated with smoking [59]. The clinical importance of MT on protein level was also shown by Athanassiadou et al. [61]. It has been shown that MT1 and MT2 tissue levels vary in individual prostate cancers to that found in the normal prostate gland, while higher MT content correlates with tumor grade. As mentioned previously, AMACR may be utilized immunohistochemically as a prostate cancer tissue biomarker [41]. In this study, we demonstrated similar results on mRNA and protein as previously shown in biopsies [62].

None of the studied markers meets requirements of marker of aggressive form of malignant disease. This predication is based on the presumption that a majority of prostate tumors is latent and slowly-growing (stages T1 and 2) and only a minority of them demonstrates aggressive growth (stages $\mathrm{T} 3$ and 4). No significant differences in monitored proteins have been determined between these two groups. However, level of patients' blood serum AMACR is of in the Gleason score 9 distinctly higher and level of MT shows a descending trend in relation to Gleason score. Although AMACR does not differ between patients and controls, this preliminary data suggest that these markers are somehow related to tumor grade. It was previously shown that AMACR, as a tissue marker for prostate cancer [41,63], is higher in high-risk forms of cancer such as untreated metastases or hormone refractory cancer [38]. Wright et al. explored the potential relationship between AMACR polymorphisms, red meat/dairy intake, and prostate cancer risk. They found that no effect modification of AMACR polymorphisms by either dietary red meat or dairy intake on PCa risk was observed [64]. Besides AMACR itself, there were identified other promising markers correlated with the presence of a tumor[65]. One may speculate that similar trend could be reflected in the serum level of AMACR as well. In conclusion, it is necessary to verify these facts in the extensive group of patients including those with disseminated (metastasizing) disease in a follow-up study. Although metallothionein does not fulfil the conditions for marker of aggressive form of disease, it is the only compound distinctively enhanced in the blood serum of patients suffering from prostate tumors in this study. It can be concluded that MT may be as the only from monitored markers used as a supplement or addition to PSA screening. However, its application must be further verified on more extensive group of patients.
Conclusions. Metallothionein has been previously demonstrated by our group as a prostate cancer tumor marker with high sensitivity and specificity [23]. In this study, we demonstrate that alpha-methylacyl-CoA racemase does not differ in serum of prostate cancer patients and controls, however, AMACR is distinctly higher in high-grade (Gleason score 9) tumors and level of MT shows a descending trend in relation to Gleason score. These preliminary data suggest that these markers are somehow related to tumor grade. At the level of tumor tissue (represented by cell line model in this study), it was demonstrated that although AMACR protein level does not differ significantly, tissue mRNA differ distinctly presented by higher levels of AMACR. In the case of metallothionein, contradictory findings on mRNA and protein level were observed. At the mRNA level, MT is higher in tumor cell line; however, MT is higher in non-tumor cell line at the protein level. Probable explanation of this assumed discrepancy is excretion of metallothionein from prostate cancer cells. These data suggest that MT and AMACR are in some way involved in disease pathogenesis or progression. Clarification of this way might contribute to understanding of this prostate cancer with potential novel targeted therapeutic approaches.

From the point of view of clinical significance of our results it can be concluded that metallothionein can be considered as a promising marker of prostate cancer. Moreover, this marker has been found elevated even in other types of cancers such as breast carcinoma [66], head and neck cancer [67], medulloblastoma[35], melanoma [68,69] and other [70-74]. Nevertheless, combination of MT and PSA levels could be of prognostic significance due to possible revealing of false positive results, but this assumption needs to be investigated in greater details. We can also suggest using AMACR, which could be used in diagnostics for some relations to Gleason score.

Acknowledgements: Financial support from IGA MZ NS10200-3 is greatly acknowledged.

\section{References}

[1] FH SCHRODER, I VAN DER CRUIJSEN-KOETER, HJ DE KONING, AN VIS, RF HOEDEMAEKER et al. Prostate cancer detection at low prostate specific antigen. J Urol 2000; 163: 806-811. http://dx.doi.org/10.1016/S00225347(05)67809-3

[2] P JANTSCHEFF, N ESSER, A GEIPEL, P WOIAS, V ZIROLI et al. Metastasizing, Luciferase Transduced MATLu Rat Prostate Cancer Models: Follow up of Bolus and Metronomic Therapy with Doxorubicin as Model Drug. Cancers 2011; 3: 2679-2695. http://dx.doi.org/10.3390/ cancers3022679

[3] G SARDANA, B DOWELL, EP DIAMANDIS. Emerging Biomarkers for the Diagnosis and Prognosis of Prostate Cancer. Clin Chem 2008; 54: 1951-1960. http://dx.doi.org/10.1373/ clinchem.2008.110668 
[4] L COLLETTE, T BURZYKOWSKI, FH SCHRODER. Prostate-specific antigen (PSA) alone is not an appropriate surrogate marker of long-term therapeutic benefit in prostate cancer trials. Eur J Cancer 2006; 42: 1344-1350. http://dx.doi. org/10.1016/j.ejca.2006.02.011

[5] IP GARRAWAY, WY SUN, CP TRAN, S PERNER, B ZHANG et al. Human Prostate Sphere-Forming Cells Represent a Subset of Basal Epithelial Cells Capable of Glandular Regeneration In Vivo. Prostate 2010; 70: 491-501.

[6] KL PENNEY, JA SINNOTT, K FALL, Y PAWITAN, Y HOSHIDA et al. mRNA Expression Signature of Gleason Grade Predicts Lethal Prostate Cancer. J Clin Oncol 2011; 29: 23912396. http://dx.doi.org/10.1200/JCO.2010.32.6421

[7] A SBONER, F DEMICHELIS, S CALZA, Y PAWITAN, SR SETLUR et al. Molecular sampling of prostate cancer: a dilemma for predicting disease progression. BMC Med Genomics 2010; 3: 8. http://dx.doi.org/10.1186/1755-8794-3-8

[8] FH SCHROEDER, J HUGOSSON, MJ ROOBOL, TLJ TAMMELA, S CIATTO et al. Screening and Prostate-Cancer Mortality in a Randomized European Study. N Engl J Med 2009; 360: 1320-1328. http://dx.doi.org/10.1056/ NEJMoa0810084

[9] DV MAKAROV, S LOEB, RH GETZENBERG, AW PARTIN. Biomarkers for Prostate Cancer. Annu Rev Med 2009; 60: 139-151.

[10] J TOSOIAN, S LOEB. PSA and Beyond: The Past, Present, and Future of Investigative Biomarkers for Prostate Cancer. TheScientificWorldJOURNAL 2010; 10: 1919-1931. http://dx.doi. org/10.1100/tsw.2010.182

[11] R RAAIJMAKERS, SH DE VRIES, BG BLIJENBERG, MF WILDHAGEN, R POSTMA et al. hK2 and free PSA, a prognostic combination in predicting minimal prostate cancer in screen-detected men within the PSA range $4-10 \mathrm{ng} / \mathrm{ml}$. Eur Urol 2007; 52: 1358-1364. http://dx.doi.org/10.1016/ j.eururo.2007.04.037

[12] LG ZHANG, CY WANG, R YANG, JD SHI, R FU et al. Realtime quantitative RT-PCR assay of prostate-specific antigen and prostate-specific membrane antigen in peripheral blood for detection of prostate cancer micrometastasis. Urol Oncol-Semin Orig Investig 2008; 26: 634-640. http://dx.doi. org/10.1016/j.urolonc.2007.07.016

[13] MA ROWLANDS, D GUNNELL, R HARRIS, LJ VATTEN, JMP HOLLY et al. Circulating insulin-like growth factor peptides and prostate cancer risk: A systematic review and meta-analysis. Int J Cancer 2009; 124: 2416-2429. http:// dx.doi.org/10.1002/ijc. 24202

[14] SK BATABYAL, R MAJHI, RS BASU. Clinical utility of the interaction between lectin and serum prostate specific antigen in prostate cancer. Neoplasma 2009; 56: 68-71. http://dx.doi. org/10.4149/neo $200901 \quad 68$

[15] T JAMASPISHVILI, A SCORILAS, M KRAL, I KHOMERIKI, D KURFURSTOVA et al. Immunohistochemical localization and analysis of kallikrein-related peptidase 7 and 11 expression in paired cancer and benign foci in prostate cancer patients. Neoplasma 2011; 58: 298-303.

[16] B DJAVAN, A KAZZAZI, L DULABON, M MARGREITER, A FARR et al. Diagnostic Strategies for Prostate Cancer. Eur
Urol Suppl 2011; 10: E26-E37. http://dx.doi.org/10.1016/ j.eursup.2011.03.010

[17] T JAMASPISHVILI, M KRAL, I KHOMERIKI, V STUDENT, $\mathrm{Z}$ KOLAR et al. Urine markers in monitoring for prostate cancer. Prostate Cancer Prostatic Dis 2010; 13: 12-19. http:// dx.doi.org/10.1038/pcan.2009.31

[18] L HUMBERT, M CHEVRETTE Somatic Molecular Genetics of Prostate Cancer, in: W.D. Foulkes and K.A. Cooney (Eds.), Male Reproductive Cancers Epidemiology, Pathology and Genetics, Springer Verlag, New York, Dordrecht, Heidelberg, London, 2009.

[19] S PUNNEN, RK NAM. Indications and timing for prostate biopsy, diagnosis of early stage prostate cancer and its definitive treatment: A clinical conundrum in the PSA era. Surg Oncol-Oxf 2009; 18: 192-199. http://dx.doi.org/10.1016/ j.suronc.2009.02.006

[20] EI CANTO, KM SLAWIN. Early management of prostate cancer: How to respond to an elevated PSA? Annu Rev Med 2002; 53: 355-368.

[21] S KRIZKOVA, M MASARIK, J KUKACKA, R PRUSA, T Eckschlager et al. Study of zinc-dependent aggregation of metallothionein from human prostatic cancer cell lines. EJC Suppl 2010; 8: 49-49. http://dx.doi.org/10.1016/S13596349(10)70993-9

[22] S KRIZKOVA, M MASARIK, P MAJZLIK, J KUKACKA, J KRUSEOVA et al. Serum metallothionein in newly diagnosed patients with childhood solid tumors. Acta Biochim Pol 2010; 57: 561-566.

[23] SKRIZKOVA, M RYVOLOVA, J GUMULEC, M MASARIK, V ADAM et al. Electrophoretic fingerprint metallothionein analysis as a potential prostate cancer biomarker. Electrophoresis 2011; 32: 1952-1961. http://dx.doi.org/10.1002/elps.201000519

[24] M MASARIK, N CERNEI, J GUMULEC, O ZITKA, P BABULA et al. Immunological determination of serum prostate specific antigen in cancer patients and tumor cell lines - New perspective. Int J Mol Med 2010; 26: S47-S47.

[25] M MASARIK, N CERNEI, P MAJZLIK, D HUSKA, H BINKOVA et al. Level of metallothionein, glutathione and heat-stable proteins in tumors from patients with head and neck cancer. Int J Mol Med 2010; 26: S46-S46.

[26] M MASARIK, J GUMULEC, S KUCHTICKOVA, V ADAM, $S$ KRIZKOVA et al. Detection of metallothionein and alpha-methylacyl CoA racemase as potential new markers for prostate carcinoma. Int J Mol Med 2009; 24: S48-S48.

[27] M MASARIK, J GUMULEC, S KUCHTICKOVA, V KUDLACKOVA, N CERNEI et al. Determination of metallothioneins and alpha-methylacyl-CoA racemase in patients with prostate carcinoma. Int J Mol Med 2010; 26: S47-S47.

[28] M MASARIK, J GUMULEC, S KUCHTICKOVA, V KUDLACKOVA, M JURAJDA et al. Determination of novel tumor markers in prostate carcinoma. FEBS J 2010; 277: 188-188.

[29] M MASARIK, J GUMULEE, N CERNEI, O ZITKA, P BABULA et al. Sarcosine as a new marker for prostate tumors. Int J Mol Med 2010; 26: S47-S47.

[30] ME MCDOWELL, S OCCHIPINTI, RA GARDINER, PD BAADE, SK STEGINGA. A review of prostate-specific 
antigen screening prevalence and risk perceptions for firstdegree relatives of men with prostate cancer. Eur J Cancer Care 2009; 18: 545-555. http://dx.doi.org/10.1111/j.13652354.2008.01046.x

[31] J PETRLOVA, D POTESIL, R MIKELOVA, O BLASTIK, $\mathrm{V}$ ADAM et al. Attomole voltammetric determination of metallothionein. Electrochim Acta 2006; 51: 5112-5119. http://dx.doi.org/10.1016/j.electacta.2006.03.078

[32] R KIZEK, L TRNKOVA, E PALECEK. Determination of metallothionein at the femtomole level by constant current stripping chronopotentiometry. Anal Chem 2001; 73: 48014807. http://dx.doi.org/10.1021/ac010126u

[33] V ADAM, I FABRIK, T ECKSCHLAGER, M STIBOROVA, L TRNKOVA et al. Vertebrate metallothioneins as target molecules for analytical techniques. TRAC-Trends Anal Chem 2010; 29: 409-418. http://dx.doi.org/10.1016/ j.trac.2010.02.004

[34] T ECKSCHLAGER, V ADAM, J HRABETA, K FIGOVA, R KIZEK. Metallothioneins and Cancer. Curr Protein Pept Sci 2009; 10: 360-375. http://dx.doi.org/10.2174/ 138920309788922243

[35] S KRIZKOVA, V ADAM, T ECKSCHLAGER, R KIZEK. Using of chicken antibodies for metallothionein detection in human blood serum and cadmium-treated tumor cell lines after dot- and electroblotting. Electrophoresis 2009; 30: 37263735. http://dx.doi.org/10.1002/elps.200900201

[36] S KRIZKOVA, I FABRIK, V ADAM, P HRABETA, T Eckschlager et al. Metallothionein - a promising tool for cancer diagnostics. Bratisl Med J 2009; 110: 93-97.

[37] R KUEFER, S VARAMBALLY, M ZHOU, PC LUCAS, M LOEFFLER et al. alpha-Methyl acyl-CoA racemase: Expression levels of this novel cancer biomarker depend on tumor differentiation. Am J Pathol 2002; 161: 841-848. http://dx.doi. org/10.1016/S0002-9440(10)64244-7

[38] J LUO, S ZHA, WR GAGE, TA DUNN, JL HICKS et al. alpha-Methylacyl-CoA racemase: A new molecular marker for prostate cancer. Cancer Res 2002; 62: 2220-2226.

[39] JC XU, JA STOLK, XQ ZHANG, SJ SILVA, RL HOUGHTON et al. Identification of differentially expressed genes in human prostate cancer using subtraction and microarray. Cancer Res 2000; 60: 1677-1682.

[40] AJ EVANS. alpha-Methylacyl CoA racemase (P504S): overview and potential uses in diagnostic pathology as applied to prostate needle biopsies. J Clin Pathol 2003; 56: 892-897. http://dx.doi.org/10.1136/jcp.56.12.892

[41] MA RUBIN, M ZHOU, SM DHANASEKARAN, S VARAMBALLY, TR BARRETTE et al. alpha-methylacyl coenzyme A racemase as a tissue biomarker for prostate cancer. JAMA-J Am Med Assoc 2002; 287: 1662-1670.

[42] RM SRAMKOSKI, TG PRETLOW, JM GIACONIA, TP PRETLOW, S SCHWARTZ et al. A new human prostate carcinoma cell line, 22Rv1. In Vitro Cell Dev Biol-Anim 1999; 35: 403-409.

[43] V ADAM, J PETRLOVA, J WANG, T ECKSCHLAGER, L TRNKOVA et al. Zeptomole Electrochemical Detection of Metallothioneins. PLoS One 2010; 5.

[44] V ADAM, O BLASTIK, S KRIZKOVA, P LUBAL, J KUKACKA et al. Application of the Brdicka reaction in determination of metallothionein in patients with tumors. Chem Listy 2008; 102: 51-58.

[45] Y OGRA, KT SUZUKI. Targeting of tetrathiomolybdate on the copper accumulating in the liver of LEC rats. J Inorg Biochem 1998; 70: 49-55. http://dx.doi.org/10.1016/S01620134(98)00012-9

[46] M KATO, W LIU, AA AKHAND, Y DAI, M OHBAYASHI et al. Linkage between melanocytic tumor development and early burst of Ret protein expression for tolerance induction in metallothionein-I ret transgenic mouse lines. Oncogene 1999; 18: 837-842. http://dx.doi.org/10.1038/sj.onc.1202329

[47] I NAKAGAWA, M SUZUKI, N IMURA, A NAGANUMA. Involvement of oxidative stress in paraquat-induced metallothionein synthesis under glutathione depletion. Free Radic Biol Med 1998; 24: 1390-1395. http://dx.doi.org/10.1016/ S0891-5849(98)00008-2

[48] K SUZUKI, K NAKAZATO, K NAKAJIMA Cadmium-induced metallothionein expression and metallothionein mRNA in mice, 1999.

[49] Y SUZUKI, Y KONDO, S HIMENO, K NEMOTO, M AKIMOTO et al. Role of antioxidant systems in human androgen-independent prostate cancer cells. Prostate 2000; 43: 144-149. http://dx.doi.org/10.1002/(SICI)10970045(20000501)43:2<144::AID-PROS9>3.0.CO;2-H

[50] K TAKABA, K SAEKI, K SUZUKI, H WANIBUCHI, S FUKUSHIMA. Significant overexpression of metallothionein and cyclin D1 and apoptosis in the early process of rat urinary bladder carcinogenesis induced by treatment with N-butyl$\mathrm{N}$-(4-hydroxybutyl)nitrosamine or sodium L-ascorbate. Carcinogenesis 2000; 21: 691-700. http://dx.doi.org/10.1093/ carcin/21.4.691

[51] BX ZHANG, M SATOH, N NISHIMURA, JS SUZUKI, H SONE et al. Metallothionein deficiency promotes mouse skin carcinogenesis induced by 7,12-dimethylbenz a anthracene. Cancer Res 1998; 58: 4044-4046.

[52] C TOHYAMA, N NISHIMURA, JS SUZUKI, M KARASAWA, H NISHIMURA. Metallothionein messenger-rna in the testis and prostate of the rat detected by digoxigenin-labeled riboprobe. Histochemistry 1994; 101: 341-346. http://dx.doi. org/10.1007/BF00268995

[53] S KOIZUMI, K SUZUKI, F OTSUKA. A nuclear factor that recognizes the metal-responsive elements of human metallothionein-iia gene. J Biol Chem 1992; 267: 18659-18664.

[54] AL ALBRECHT, RK SINGH, S SOMJI, MA SENS, DA SENS et al. Basal and metal-induced expression of metallothionein isoform 1 and 2 genes in the RWPE- 1 human prostate epithelial cell line. J Appl Toxicol 2008; 28: 283-293. http://dx.doi. org/10.1002/jat.1277

[55] H WEI, MM DESOUKI, S LIN, D XIAO, RB FRANKLIN et al. Differential expression of metallothioneins (MTs) 1, 2, and 3 in response to zinc treatment in human prostate normal and malignant cells and tissues. Mol Cancer 2008; 7: 1-7. http://dx.doi.org/10.1186/1476-4598-7-7

[56] M YAMASAKI, T NOMURA, F SATO, H MIMATA. Metallothionein is up-regulated under hypoxia and promotes the survival of human prostate cancer cells. Oncol Rep 2007; 18: 1145-1153. 
[57] T SUZUKI, H YAMANAKA, Y TAMURA, K NAKAJIMA, K KANATANI et al. Metallothionein of prostatic tissues and fluids in rats and humans. Tohoku J Exp Med 1992; 166: 251257. http://dx.doi.org/10.1620/tjem.166.251

[58] YCWONG, YZ WANG, JSK LEE, NNC TAM, D LEE. Changes in serum and tissue zinc levels in sex hormone-induced prostatic carcinogenesis in the Noble rat. Tumor Biol 2000; 21: 328-336. http://dx.doi.org/10.1159/000030138

[59] JD LEE, SM WU, LY LU, YT YANG, SY JENG. Cadmium Concentration and Metallothionein Expression in Prostate Cancer and Benign Prostatic Hyperplasia of Humans. J Formos Med Assoc 2009; 108: 554-559. http://dx.doi.org/10.1016/S09296646(09)60373-9

[60] J SCHOPFER, G DRASCH, GN SCHRAUZER. Selenium and Cadmium Levels and Ratios in Prostates, Livers, and Kidneys of Nonsmokers and Smokers. Biol Trace Elem Res 2010; 134: 180-187. http://dx.doi.org/10.1007/s12011-010-8636-y

[61] P ATHANASSIADOU, A BANTIS, M GONIDI, P ATHANASSIADES, E AGELONIDOU et al. The expression of metallothioneins on imprint smears of prostate carcinoma: Correlation with clinicopathologic parameters and tumor proliferative capacity. Tumori 2007; 93: 189-194.

[62] Z JIANG, BA WODA. Diagnostic utility of alpha-methylacyl CoA racemase (P504S) on prostate needle biopsy. Adv Anat Pathol 2004; 11: 316-321. http://dx.doi.org/10.1097/01. pap.0000146924.14246.be

[63] C XIE, HJ KIM, JG HAW, A KALBASI, BK GARDNER et al. A novel multiplex assay combining autoantibodies plus PSA has potential implications for classification of prostate cancer from non-malignant cases. J Transl Med 2011; 9.

[64] JL WRIGHT, ML NEUHOUSER, DW LIN, EM KWON, ZD FENG et al. AMACR Polymorphisms, Dietary Intake of Red Meat and Dairy and Prostate Cancer Risk. Prostate 2011; 71: 498-506. http://dx.doi.org/10.1002/pros.21267

[65] XJ WU, M ZAYZAFOON, XZ ZHANG, O HAMEED. Is There a Role for Fatty Acid Synthase in the Diagnosis of Prostatic Adenocarcinoma? A Comparison With AMACR. Am J Clin Pathol 2011; 136: 239-246. http://dx.doi.org/10.1309/ AJCP0Y5QWWYDKCJE
[66] V ADAM, J BALOUN, I FABRIK, L TRNKOVA, R KIZEK. An electrochemical detection of metallothioneins at the zeptomole level in nanolitre volumes. Sensors 2008; 8: 2293-2305. http://dx.doi.org/10.3390/s8042293

[67] I FABRIK, S KRIZKOVA, D HUSKA, V ADAM, J HUBALEK et al. Employment of electrochemical techniques for metallothionein determination in tumor cell lines and patients with a tumor disease. Electroanalysis 2008; 20: 1521-1532. http://dx.doi.org/10.1002/elan.200704215

[68] S KRIZKOVA, I FABRIK, V ADAM, J KUKACKA, R PRUSA et al. Utilizing of adsorptive transfer stripping technique Brdicka reaction for determination of metallothioneins level in melanoma cells, blood serum and tissues. Sensors 2008; 8: 3106-3122. http://dx.doi.org/10.3390/s8053106

[69] S KRIZKOVA, I FABRIK, V ADAM, J KUKACKA, R PRUSA et al. Effects of reduced glutathione, surface active agents and ionic strength on the detection of metallothioneins by using of Brdicka reaction. Electroanalysis 2009; 21: 640-644. http://dx.doi.org/10.1002/elan.200804406

[70] RA GOYER, J LIU, MP WAALKES. Cadmium and cancer of prostate and testis. Biometals 2004; 17: 555-558. http://dx.doi. org/10.1023/B:BIOM.0000045738.59708.20

[71] MO PEDERSEN, A LARSEN, M STOLTENBERG, M PENKOWA. The role of metallothionein in oncogenesis and cancer prognosis. Prog Histochem Cytochem 2009; 44: 29-64.

[72] OJK TAN, BH BAY, VTK CHOW. Differential expression of metallothionein isoforms in nasopharyneal cancer and inhibition of cell growth by antisense down-regulation of metallothionein-2A. Oncol Rep 2005; 13: 127-131.

[73] B WERYNSKA, B PULA, B MUSZCZYNSKA-BERNHARD, A PIOTROWSKA, A JETHON et al. Correlation between Expression of Metallothionein and Expression of Ki-67 and MCM-2 Proliferation Markers in Non-Small Cell Lung Cancer. Anticancer Res 2011; 31: 2833-2839.

[74] D LAUKENS, A WAEYTENS, P DE BLESER, C CUVELIER, M DE VOS. Human Metallothionein Expression under Normal and Pathological Conditions: Mechanisms of Gene Regulation Based on In silico Promoter Analysis. Crit Rev Eukaryot Gene Expr 2009; 19: 301-317. 